\title{
Recurrent Clear Cell Renal Cell Carcinoma
}

National Cancer Institute

\section{Source}

National Cancer Institute. Recurrent Clear Cell Renal Cell Carcinoma. NCI Thesaurus.

Code C153590.

The reemergence of clear cell renal cell carcinoma after a period of remission. 